\title{
LOW MACRO-ARTHROPOD ABUNDANCE IN EXOTIC EUCALYPTUS PLANTATIONS IN THE MEDITERRANEAN
}

\author{
A. ZAHN $^{1} *-$ A. RAINHO ${ }^{2}-$ L. RODRIGUES ${ }^{2}-$ J.M. PALMEIRIM ${ }^{3}$ \\ ${ }^{1}$ Ludwig-Maximilians-Universät München, München, Germany \\ ${ }^{2}$ Instituto da Conservação da Natureza e da Biodiversidade, Lisboa, Portugal \\ ${ }^{3}$ Centro de Biologia Ambiental, Departamento de Biologia Animal, Faculdade de Ciências, \\ Universidade de Lisboa, Lisboa, Portugal \\ *Corresponding author \\ email: andreas.zahn@iiv.de
}

(Received $24^{\text {th }}$ March 2009 ; accepted $13^{\text {th }}$ November 2009)

\begin{abstract}
Exotic plantations of Eucalyptus are replacing large areas of extensive agroecosystems throughout the Mediterranean basin. A comparison of the abundance of ground macro-arthropods in some of major types of traditional land uses in southern Iberia (cork oak woodlands, olive groves, fallow fields, vineyards, and riparian vegetation) revealed that Eucalyptus plantations held the lowest abundances for most groups of arthropods. This indicates that the expansion of Eucalyptus plantations in the Mediterranean is very negative for ground arthropods, and for the many species of vertebrates that depend on them as prey.
\end{abstract}

Keywords: Exotic plantations, landscape management, ground arthropods

\section{Introduction}

Throughout the Mediterranean basin exotic Eucalyptus plantations are replacing large areas of native woodland and traditional extensive agroecosystems, such as olive grove or cork oak woodland [4]. However, since plantation forests tend to be unfavourable habitat for a wide range of animal taxa, particularly in the case of evenaged, single-species stands of exotic species, the expansion of these plantations may pose problems for the preservation of Mediterranean biodiversity $[6,13]$.

In spite of the generalized use of Eucalyptus in forestry in many parts of the World, there is little information on its impact on the invertebrate fauna, and most existing studies focus on the impact of single groups. In addition, the results of different studies carried out throughout the World do not allow a general conclusion about the influence of the plantations on the abundance of invertebrates. Although most studies report a negative influence on invertebrates (e.g. [5,9]), a few found invertebrate communities in plantations that are similar in abundance or diversity to those of neighbouring natural or semi-natural habitats (e.g. $[1,10])$. This diversity of results suggests that the response of arthropods to Eucalyptus plantations varies among taxa and depends on the geographic context and other environmental factors, so specific studies are needed to understand the impact of plantations in different ecological regions.

Although the high biodiversity value of the Mediterranean basin led to its classification as a Biodiversity Hotspot, little is known about how the expansion of Eucalyptus plantations may be affecting the epigeic invertebrate communities in the region. Such knowledge is important not only because of the intrinsic value of those communities, but also because of the many species that depend on them as prey. The objective of this study is to evaluate how the abundance of ground macro-arthropods in 
Eucalyptus plantations in southern Iberia compares with that of some of the main land uses that they are replacing, namely cork oak woodlands, olive groves, vineyards, riparian vegetation and fallow farmland.

\section{Methods}

The study was conducted from March 1997 to February 1998 near Évora, Portugal ( $\left.8^{\circ} 8^{\prime} \mathrm{W}, 38^{\circ} 29^{\prime} \mathrm{N}\right)$, a region with a Mediterranean to sub-Mediterranean climate, with cool and rainy winters and dry hot summers.

Arthropods were sampled in the main land cover types of the area, which are also common throughout much of Mediterranean Iberia: (i) cork oak woodland, with sparse trees (Quercus suber) and an undergrowth of sparse shrubs and herbs; (ii) olive grove, with olive trees (Olea europaea) and herbs; (iii) fallow field, sparsely covered with grasses; (iv) vineyard, culture of Vitis vinifera on regularly plough and mostly bare ground; (v) riparian vegetation, well vegetated areas along stream banks; and (vi) Eucalyptus plantation, stands of Eucalyptus globulus with some Cistus shrubs growing on mostly bare ground. Although Eucalyptus has been used in the area since 1964, the trees of the studied plantation were 6 to 7 years old. This age is quite representative of the Eucalyptus plantations in the region, which are maintained on short rotations, mostly for the production of pulp for the paper industry.

Three sets of four pitfall traps $(10.5 \times 17.0 \mathrm{~cm}, 10 \mathrm{~cm}$ deep) were placed 50-100 meters apart in each of the six above listed habitats. Traps were partly filled with saltwater to preserve captured arthropods, and kept open for 6 days in March, June, July, September, and November 1997 and in February 1998, so we had a total of 432 trap days for each habitat. Samples were frozen and analyzed in the lab, where arthropods were identified at least to order. Numbers of individuals in each trap were counted and averaged for each habitat type.

The comparison of the abundances of arthropods in Eucalyptus plantations with those in other major land uses is based on the most common groups of typical grounddwelling arthropods: Isopoda, Arachnida, Formicidae and Carabidae (Table 1). Arthropods that were not sufficiently represented to justify its own class were included in either "other coleoptera" or "other arthropods" (mainly Grylloidea, Chilopoda, Heteroptera, larvae of Lepidoptera, and Diptera). The comparison of the samples of the Eucalyptus plantation to those of other habitats was done using Scheffé-Test after significant differences between habitats were proven by the H-Test.

\section{Results and Discussion}

Ground macro-arthropods caught in the pitfall traps included Arachnida (Scorpiones, Solifugae, Araneae, Opiliones, Acari), Myriapoda (Chilopoda, Diplopoda), Crustacea (Isopoda) and Insecta (Saltatoria, Dermaptera, Blattodea, Hemiptera, Lepidoptera, Diptera, Hymenoptera, Coleoptera).

Riparian habitats had the highest abundance of all but two groups (Isopoda and Formicidae; Table 1), which may be explained by the greater moisture available in its soil. Cork oak woodlands held the next highest overall abundances, and the highest values for Arachnida, Formicidae, Carabidae and "other arthropods". This may be due to the greater relative complexity of this habitat, and to the fact that it is presumably the most similar to the original natural vegetation of the region. Eucalyptus plantation had 
the lowest abundances of all groups of arthropods (Table 1), with the exception of Isopoda, which are detritivores and can probably benefit from the high amount of leaflitter in them [11]. In most other groups, the abundance in Eucalyptus plantations was several times lower than that of the best habitats in the region.

Table 1. Abundance of different ground macro-arthropod groups in the studied habitats (mean number of specimens per trap in each sampling session and standard error). Grey tones represent the rank from higher (light) to lower (dark) abundance. An * indicates a significant difference $(p<0,05)$ in tests comparing the abundance between each land use and the Eucalyptus plantations.

\begin{tabular}{|c|c|c|c|c|c|c|c|}
\hline HABITAT & Isopoda & Formicidae & Arachnida & Carabidae & $\begin{array}{c}\text { Other } \\
\text { Coleopt }\end{array}$ & $\begin{array}{c}\text { Other } \\
\text { Arthrop }\end{array}$ & $\begin{array}{c}\text { Large } \\
\text { Arthrop }\end{array}$ \\
\hline $\begin{array}{c}\text { Riparian } \\
\text { vegetation }\end{array}$ & $2.36(0.63)$ & $1.93(0.24)$ & $13.66(1.68) *$ & $1.77(0.35 * *$ & $4.32(0.97) *$ & $9.41(1.47)^{*}$ & $1.23(0.26) *$ \\
\hline $\begin{array}{c}\text { Oak } \\
\text { woodland }\end{array}$ & $1.26(0.21)$ & $3.44(0.17)^{*}$ & $5.05(0.43)^{*}$ & $1.35(0.24)^{*}$ & $0.88(0.13)$ & $3.94(0.81)$ & $0.93(0.17)$ \\
\hline Olive grove & $1.16(0.28)$ & $3.18(0.25)^{*}$ & $4.73(0.55)$ & $0.55(0.16)$ & $0.47(0.13)$ & $3.63(0.41)$ & $0.61(0.18)$ \\
\hline Fallow field & $0.23(0.07)$ & $3.08(0.24)^{*}$ & $4.19(0.41)$ & $1.15(0.27)^{*}$ & $2.56(0.73)^{*}$ & $2.87(0.35)$ & $0.63(0.12)$ \\
\hline Vineyard & $2.45(0.67)$ & $2.88(0.24)^{*}$ & $4.66(0.42)$ & $0.55(0.12)$ & $0.43(0.13)$ & $2.64(0.38)$ & $0.50(0.10)$ \\
\hline $\begin{array}{c}\text { Eucalyptus } \\
\text { plantation }\end{array}$ & $2.70(0.72)$ & $1.46(0.16)$ & $2.01(0.27)$ & $0.17(0.06)$ & $0.37(0.08)$ & $1.94(0.34)$ & $0.45(0,07)$ \\
\hline
\end{tabular}

One possible explanation for the low number of arthropods in Eucalyptus plantations is the usually low density and diversity of herbs and shrubs, which can be attributed to a variety of factors. Mechanical treatments of the soil prior to planting or at middle rotation are known to reduce the diversity, ground cover, and biomass of the undergrowth [3]. The release of phytotoxic substances by Eucalyptus globulus, is likely to have similar effects on the undergrowth [12]. Nutrient deficiencies may limit plant growth in older stands that have been used for multiple rotations, due to the export of nutrients by harvesting [7]. Finally, Eucalyptus are known to be very efficient competitors for water, which under certain circumstances may limit the development of undergrowth [8].

Another factor that may contribute to the low abundances of arthropods in the plantations is the direct effect of Eucalyptus leaves leachates on them, as it has been demonstrated that the leachates of E. globulus reduce the viability of certain arthropod species (e.g. [2]).

As many species of Mediterranean vertebrates prey on the larger ground arthropods, we estimated the abundance of individuals more than $1 \mathrm{~cm}$ long in the six habitats. We found that these larger individuals are also least abundant in the Eucalyptus plantations (Table 1), which should negatively influence their potential as foraging habitats for many vertebrates.

The impact of the reduction of arthropods was less pronounced in the wetter sampled areas of the Eucalyptus plantations (Fig. 1). They had better developed undergrowth, presumably because of the greater availability of water, and a greater abundance of all groups of macro-arthropods, with the exception of Carabidae. The difference was significant in Isopoda and "other arthropods" ( $p<0,05$; Wilcoxon-test). This is coherent with the results of studies carried out in plantations of E. globulus in northern Iberia, which has a much higher rainfall; the plantations had well developed undergrowth and a 
fauna of leaf-litter invertebrates similar in composition and density to that of nearby native forest [1].

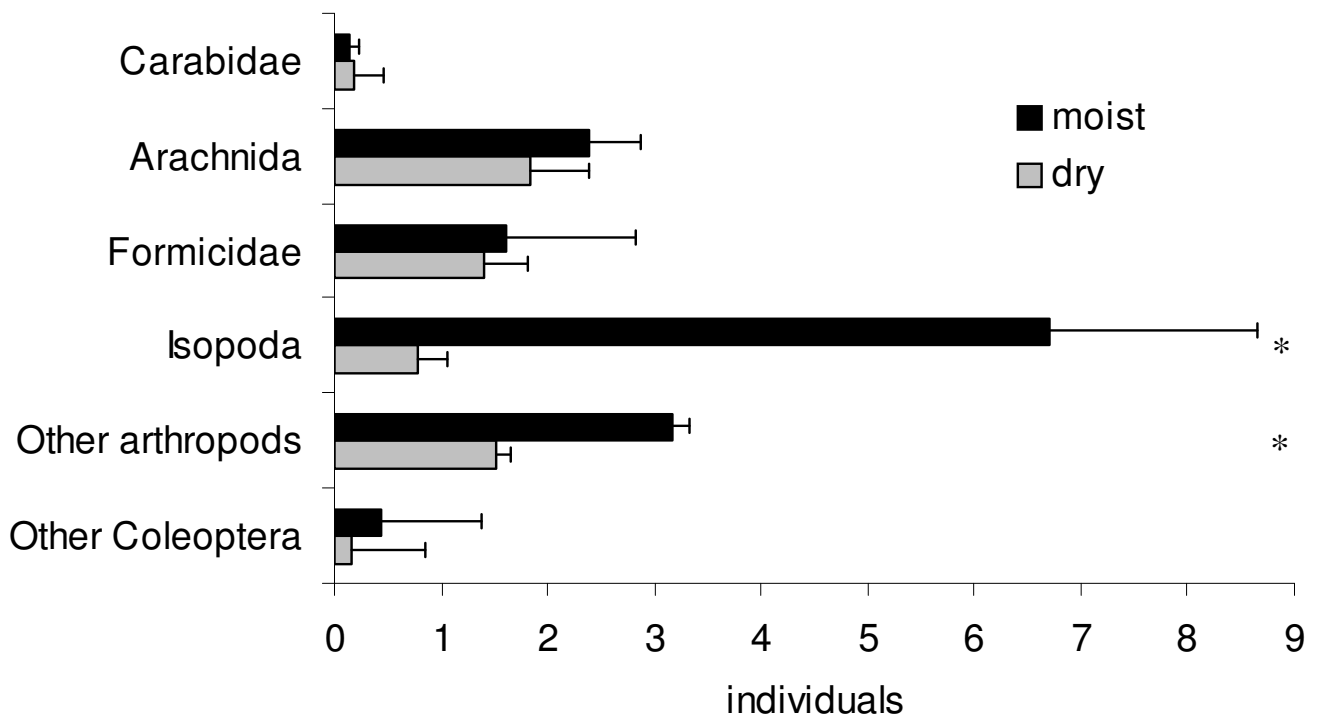

Figure 1. Abundance of ground macro-arthropods in the moist and the dry sections of the Eucalyptus globulus plantation. Columns represent mean number of specimens per trap in each sampling session and lines the standard error. An * indicates a significant difference $(p<0,05)$

The environmental factors that control the abundance of arthropods in exotic stands of Eucalyptus are diverse, although poorly understood. In addition to water availability, the age of the trees seems to be very important, as old plantations can harbour abundant faunas [10]. Consequently, our results can not be extrapolated to all Eucalyptus plantations in the Mediterranean, as we only studied young stands. However, they do suggest that these stands, which are by far the most widespread in the region, under the dry conditions typical of its climate, harbour small abundances of ground macroarthropods. Consequently, the expansion of Eucalyptus plantations, at the expense of other traditional types of land use, should be seen as a challenge to the preservation of Mediterranean biodiversity.

Acknowledgements: We are indebted to M. J. Pereira and H. Rebelo and other colleagues who helped us during fieldwork.

\section{REFERENCES}

[1] Bará, S., Rigueiro, A., Gil, M.C., Mansilla, P., Alonso, M. (1985): Efectos ecológicos del Eucalyptus globulus en Galicia. Estudio comparativo con Pinus pinaster y Quercus robur. - Instituto Nacional de Investigaciones Agrarias, Madrid.

[2] Canhoto, C., Laranjeira, C. (2007): Leachates of Eucalyptus globulus in intermittent streams affect water parameters and invertebrates. - International Review of Hydrobiology 92: 173-182.

[3] Carneiro, A., Fabião, A., Martins, M.C., Fabião, A., da Silva, M.A., Hilário, L., Lousã, M., Madeira, M. (2008): Effects of harrowing and fertilisation on understory vegetation 
and timber production of a Eucalyptus globulus Labill. plantation in Central Portugal. Forest Ecology and Management 255: 591-597.

[4] Carnus, J.M., Parrotta, J., Brockerhoff, E., Arbez, M., Jactel, H., Kremer, A., Lamb, D., O'Hara, K., Walters, B. (2006): Planted forests and biodiversity. - Journal of Forestry 104: 65-77.

[5] da Silva, P.M., Aguiar, C.A.S., Niemela, J., Sousa, J.P., Serrano, A.R.M. (2008): Diversity patterns of ground-beetles (Coleoptera: Carabidae) along a gradient of land-use disturbance. - Agriculture Ecosystems \& Environment 124: 270-274.

[6] Hartley, M.J. (2002): Rationale and methods for conserving biodiversity in plantation forests. - Forest Ecology and Management 155: 81-95.

[7] Merino, A., Balboa, M.A., Soalleiro, R.R., Gonzalez, J.G.A. (2005): Nutrient exports under different harvesting regimes in fast-growing forest plantations in southern Europe. - Forest Ecology and Management 207: 325-339.

[8] Poore, M.E.D., Fries, C. (1985): The ecological effects of eucalyptus. - Food and Agriculture Organization, Rome.

[9] Ratsirarson, H., Robertson, H.G., Picker, M.D., van Noort, S. (2002): Indigenous forests versus exotic eucalypt and pine plantations: a comparison of leaf-litter invertebrate communities. - African Entomology 10: 93-99.

[10] Sax, D.F. (2002): Equal diversity in disparate species assemblages: a comparison of native and exotic woodlands in California. - Global Ecology and Biogeography 11: 4957.

[11] Sousa, J.P., Vingada, J.V., Loureiro, S., da Gama, M.M., Soares, A. (1998): Effects of introduced exotic tree species on growth, consumption and assimilation rates of the soil detritivore Porcellio dilatatus (Crustacea : Isopoda). - Applied Soil Ecology 9: 399-403.

[12] Souto, X.C., Bolano, J.C., Gonzalez, L., Reigosa, M.J. (2001): Allelopathic effects of tree species on some soil microbial populations and herbaceous plants. - Biologia Plantarum 44: 269-275.

[13] Stephens, S.S.,Wagner, M.R. (2007): Forest plantations and biodiversity: A fresh perspective. - Journal of Forestry 105: 307-313. 